\title{
Establishment of Entrepreneurial Character in the Foundation based School System through Project Based Learning
}

\author{
Lelahester Rina ${ }^{1}$, Wiedy Murtini ${ }^{2}$, Mintasih Indriayu ${ }^{2}$
}

\section{ARTICLE INFO}

Article History:

Received 27.06.2018

Received in revised form -

Accepted 24.08.2018

Available online 01.10.2018

\begin{abstract}
Establishing entrepreneurial character is pretty much essential to be taught in educational institution. This could even be given from the elementary level of education since it is a lifelong learning of an individual. The purpose of this research is to analyze the establishment process of entrepreneurial character in students through the implementation of learning activities based on project. Research is based on interesting phenomena, creativity, innovation, and self-confidence in taking risks in students in the entrepreneurial learning process that has to do with product creation and entrepreneurship in schools starting from elementary education to secondary education. This research was conducted with qualitative methods using snowball sampling with data collection techniques of observation, interviews, documentation and also data triangulation to validate the collected data. Data analysis used analy sis techniques from Spradley through domain analy sis and semantic relationships. The results showed that the process of learning activities based on the project can shape the character of students' entrepreneurship according to the level of education. Characters in elementary school students were independent, creative, honest and disciplined. Junior high school formed entrepreneurial charac ters such as: Self-sufficient, creative, responsibility, cooperation, hard work, risk-taking and communicative. While high school students formed characters of selfsufficient, creative, responsibility, cooperation, hard work, brave to take risks and communicative, leadership and success-oriented.
\end{abstract}

C 2018 IJERE. All rights reserved

Keywords: ${ }^{1}$

Entrepreneurial Character, Project Based Learning, Entrepreneurship Education, Elementary Education, Secondary Education

\section{INTRODUCTION}

The development of science and technology should be carried out along with the obligation to contribute to the improvisation of the social and economic development of a country. The development of entrepreneurial mindset and character can be used as a tool to aid the development and global economic competition today (Robles and Rodriguez, 2015; Luca and Cazan, 2011). This is in accordance with Presidential Regulations Number 4 of 1995 in the National Movement to Promote and advocate Entrepreneurship in different fields of life. Education, as mentioned in the regulation, is one of the fields that need to promote entrepreneurship. Education plays an important role to instill some of the competencies and characters crucial if a person aimed to become successful entrepreneurs (Ismail, Zain, and Zulihar, 2015; Gutiérrez and Baquero, 2017). Thus, the introduction and active advocacy of the entrepreneurship characters have become a crucial step in shaping one's personal qualities in order to be able to compete in the current time (Gutiérrez and Baquero, 2017; Bindah and Magd, 2016; Kadir, Salim and Kamarudin, 2012).

The entrepreneurial education program aims at the shaping of skills, knowledge, attitude and character of entrepreneurship through integration in primary, secondary and tertiary education (Barba-Sánchez and Atienza-Sahuquillob, 2018; Luca and Cazan, 2011). This integration implies that entrepreneurship education is not exclusively available on the higher education but can also be applied in primary education. How ever entrepreneurial characters development in each level of education has a different character achievement orientation. Each level of school education plays a role in providing a learning experience that can increase students' interest in entrepreneurship and through these the student's entrepreneurship character can be either directly or indirectly shaped. As a foundation for the implementation of entrepreneurial education, it is necessary to foster some entrepreneurial characters that students can aspire to. This is necessary to prepare students to face their contemporary w ork and their well-being in the future (Küttim, Kallaste, Venesaar and Kiis, 2014). Preparation in equipping students' social and emotional skills related to their lifelong learning through all learning activities both formally and informally (Akcaalan, 2016). This is supported by the

\footnotetext{
${ }^{1}$ Corresponding e-mail: lelahester@student.uns.ac.id,orcid.org/0000-0003-3058-3174, 2, Sebelas Maret University,
} 
research of Okten (2016), the involvement of parents plays an important role in the education of children because the collaboration betw een school and parent will have an impact on successful schooling in terms of achievement and well-educated students.

The Ministry of National Education, Development Agency and Curriculum Center (2010) described some entrepreneurial characters that are instilled in various levels of basic education to secondary education: 1) independent, 2) creative, 3) dare to take risks, 4) action oriented, 5) leadership, 6) hard work, 7) honest, 8) discipline, 9) innovative, 10) responsibility, 11) cooperation, 12) tenacity, 13) commitment, 14) realistic, 15) curiosity, 16) communicative, and 17) strong motivation for success. Through activities in entrepreneurship education, several characters would hopefully be instilled; this could become references in further implementation, especially in intracuricular activities (Gutiérrez and Baquero, 2017). The characters that are formed in the learning process are not only sensed by students but can also be seen in the characteristics of their prominent personality (Bikse and Riemere, 2013; Luca, Cazan and Tomulescu, 2013). Thus, schools provide important foundation in efforts to create preferable and competitive human resources in the current era of information and communication technology development (Gutiérrez and Baquero, 2017; Bikse and Riemere, 2013).

Strategies in entrepreneurship education can be implemented through: interactive learning and sustainable learning, involving students in direct learning activities, making business plans and running business simulations (Bindah and Magd, 2016; Kadir, Salim and Kamarudin, 2012). There are various learning methods; one of those methods that suitable to be applied in the process of entrepreneurship education is project-based learning (Küttim, Kallaste, Venesaar and Kiis, 2014). Project-based learning is a pedagogical strategy of learning by working on complex projects for a long period of time leading to deeper knowledge of the subject related to the project (Ergül \& Kargin, 2014; Ciftci, 2015). This type of learning can increase knowledge, students' ability to learn and prepare students in professional practice (Fernandes, 2014).

Entrepreneurship project-based learning can be done through learning activities that can provide experience to have self-confidence in taking risks and innovating through activities outside the classroom as a collaborative part in developing learning and entrepreneurship experiences and providing facilities for "learning by doing" activities (Gutiérrez and Baquero, 2017). In addition, students in this learning will be motivated by active behavior because they have been processing on experiential learning, problem solving, producing creativity and innovation (Küttim, Kallaste, Venesaar, and Kiis, 2014).

This approach prioritizes meaningful learning, especially in the scope of the project, increasing motivation, and students' active involvement in learning (Goldstein, 2016). Students 'involvement is the main focus in the project-based learning process. This will provide an experience for students to think creatively and innovatively in completing the project assignments that requires a continuous process within a certain period of time. Thus the project-based learning model develops is important because it promotes collaborative skills and strengthens interpersonal interaction between the students in completing assigned projects.

Project-based learning provides learning opportunities designed by teachers to train students to simulate activities and apply the theories acquired to practice. According to Fitzsimons and Turner (2013) project learning was identified as an effective learning in developing the skills needed by employers. Projectbased learning will develop students 'various work skills. Students will explore their abilities and problem solving repertoire to be able to complete what is given by the teacher, individually or in groups. This will provide a stimulus for the student's creativity in finding and creating a particular way of completing the project properly. In addition, this learning provides opportunity so that the students can be more productive, communicative and be an active participant in learning process (Riley, 2002).

Linking education with entrepreneurial activities is essential, even more so in the era of global economic development. Indonesian government in particular has provided guidance so that education can also play a role in the introduction of entrepreneurship to students from various levels of education. Education can encourage the grow th of entrepreneurial character in many occasions of school activities. The results of the study by Welsh, Tullar and Nemati (2016) suggest that education provides activities related to knowledge, skills and character in entrepreneurial practices. This is also supported by Rohmawati's (2018) 
research, explaining that simulations in social skills can be provided through daily activities in schools, so teachers must design the implementation time and types of activities that will becarried out by students.The process of forming entrepreneurial character can be given starting from early to the next stage of education (Gutierrez and Baquero, 2017). Therefore, to instill entrepreneurship character is crucial in the process of various levels of education at this time. This will provide positive perceptions of entrepreneurship to students and will further foster entrepreneurial character from an early educational level. Instilling entrepreneurship in such way will also have an impact on increasing students`entrepreneurship character and prepare them upon entering the next level of education. This is an essential mentality needed in the global competition, so it is relevant when education is oriented to the development of entrepreneurial skills and character in students from an early age and carried out continuously.

In reality, however, in the City of Salatiga the formation of knowledge, skills, and character of entrepreneurship has not affected school graduates for primary to secondary education. The Central Statistics Agency of Salatiga (2018) showed that there is still an open unemployment rate according to the highest education level, elementary schools totaling 10,879 people, junior high schools as many as 19,651 people, senior high schools 16,507 people and vocational high schools 24,206. This shows the formation of character and entrepreneurial skills is still low it has not led to graduates that are ready to compete in the current global economic competition. In addition, according to the main employment status in Salatiga, the number of self-employed population is 15,260 , while the population with employment status as laborers / employees is 6,948 people (Statistic Center of Salatiga City, 2018). Thus the status of the main occupation of Salatiga City residents is more as laborers / employees than as entrepreneurs. People are more interested in finding work compared to creating creative business opportunities.

Based on data from the Central Statistics Agency of Salatiga City (2018) there were a number graduates from various levels of education who have not implemented the knowledge, competencies and characters of entrepreneurship that have been obtained from the education level. Knowledge, competence and entrepreneurial character that have been given through education should be used as a provision for creating jobs. Creativity, innovation and risk taking are things that need to be used as their guidance in entering the workplace. However, this is still less than optimal with the data showing that the number of open unemployed is based on the level of education and the employment status that is widely chosen by the residents of Salatiga City.

\section{Situation of the Problem}

Several studies have suggested that entrepreneurship education needed to be practiced in the learning process especially in a project (Bindah and Magd, 2016; Kadir, Salim and Kamarudin, 2012; Küttim, Kallaste, Venesaar and Kiis, 2014; Gutiérrez and Baquero, 2017; Goldstein, 2016). Based on interviews and observations in elementary schools, the Satya Wacana Christian Middle School in Salatiga still shows the priority of forming the character of entrepreneurship is still limited in school. Some perceptions of craft and entrepreneurship teachers in junior high schools and in high schools revealed that entrepreneurship programs have not been provided in a real and integrated manner in school programs. The focus of student achievement in junior and senior high school level still prioritized on academic-based learning, putting aside a number of things related to entrepreneurial practice. This can also be seen from the facilities and infrastructure provided by schools that are prioritized for some Olympic-based subjects or other academic subjects. Furthermore, mentoring in achieving academic achievements related to the Olympic subjects is highly prioritized compared to other subjects.

The development of entrepreneurship skills and characters is one of the important efforts in equip ping young Indonesians today to prepare themselves for global economic competition (Rokhman, Syaifudin, and Yuliati, 2014). Learning that only refers to concepts and understanding on several entrepreneurial theories will give different results if done by completing projects related to entrepreneurship (Fitzsimons and Turner, 2013; Gutiérrez and Baquero, 2017; Küttim, Kallaste, Venesaar, and Kiis, 2014; Goldstein, 2016). There are still teachers and schools that yet to realize the importance of promoting the character of entrepreneurship which will be useful as a weapon upon entering the w orking w orld th at requires high qualifications (Küttim, 
Kallaste, Venesaar, and Kiis, 2014; Nasr and Boujelbene, 2014). Therefore, it is important to study the efforts of character building in students through the learning process oriented to project (Küttim, Kallaste, Venesaar, and Kiis, 2014; Nasr and Boujelbene, 2014

Based on the results of interviews and preliminary observations conducted by researchers in elementary schools, junior high schools and senior high schools in the Satya Wacana Christian Higher Education Foundation Salatiga, there is an interesting phenomena found such as creativity, innovation, and self-confidence in taking risks in the learning process of the entrepreneurship subjects. Students from basic education to secondary education are involved in project learning that resulting in creating products and entrepreneurship in schools. Elementary students have been taught to make products starting from grade 1 to grade 6, Junior High School students are provided with projects. Crafts from grade 7 to grade 9 and even grade 9 are oriented tow ards product sales, and high school students from grades 10 through 12 have been guided and directed in the entrepreneur ship project by making business plans first and selling the results of their entrepreneurial project activities. This phenomenon makes researchers interested in exploring the process of forming entrepreneurial characters in the students. This phenomenon happens not only at the level of secondary education, entrepreneurship has begun since primary education.

\section{Aim of the Study}

The purpose of this research is to analyze how the project-based learning process shape the entrepreneurial character in foundation based school system. The project based learning related to entrepreneurial practices that can motivate and equip the skills of an entrepreneur (Fitzsimons and Turner, 2013; Goldstein, 2016; Welsh, Tullar and Nemati, 2016; Bindah and Magd, 2016; Kadir, Salim and Kamarudin, 2012). The purpose of project based learning as learning and teaching strategies so it can be mix with entrepreneurial character building. With the introduction of entrepreneurship in schools that can bring character to the learning process, teachers are expected to be able to direct and guide an activity that stimulates creativity and innovation (Goldstein, 2016; Bell, 2015). Based on the objectives, the problem in that will be discussed in this study is: How can the project-based learning process shape the entrepreneurial character in foundation based school system?

\section{METHOD}

This research was carried out with qualitative methods by exploring problems and developing a detailed understanding of the phenomenon of entrepreneurial character development carried out through project-based learning activities (Creswell, 2015). This is intended to analyze the implementation of learning activities based on projects related to product creation and entrepreneurship. Through the project-based learning process researchers want to study the process of forming entrepreneurial characters in students. Through the project-based learning process researchers want to study the process of forming entrepreneurial characters in students. The creation of entrepreneurial character as a way for educational institutions to equip graduates to meet the quality standards needed in the current era of global competition (Gutiérrez and Baquero, 2017; Küttim, Kallaste, Venesaar and Kiis, 2014; Bindah and Magd, 2016; Kadir, Salim and Kamarudin, 2012; Robles and Rodriguez, 2015; Luca and Cazan, 2011). Special attention given by school foundations with continuous levels of education is expected to have better results compared to educational institutions with separate levels without continuity and sustainability in promoting the character of entrepreneurship at various levels of education (Barba-Sanchez and Atienza-Sahuquillob, 2018; Gutiérrez and Baquero, 2017). The study was conducted at the Satya Wacana Christian College Foundation, Salatiga, Indonesia. The research was conducted at the Satya Wacana Christian Elementary School,Satya Wacana Christian Junior High School, andSatya Wacana Christian Senior High School.

\section{Material}

This research was conducted at the Satya Wacana Christian Higher Education Foundation Salatiga, Satya Wacana Christian Elementary School, Satya Wacana Christian Middle School, and Satya Wacana Christian High School. The technique of determining the subject of this research was by using the puposive sampling technique through snowball sampling by asking for recommendations from participants interviewed to show other participants who are considered to understand or have information (Creswell, 2015). 
The data collection techniques in this study were in depth-interviews, observationand documentation of the learning activities in the Skills and Crafts subject for elementary schools, for Junior High Schools and Craft dan Entrepreneurship subjects for the High School. Interviews are conducted with in-depth interview techniques by obtaining in-depth information and the researcher was free to ask questions that have been made beforehand. While observations are made through non-participation observation or by visiting the place and taking notes without being involved in the activities being observed. Documentation is carried out with documents that can support the data collection process in the field.

After the data collection, the researcher then conducted a technical triangulation of the data; this is a type triangulation of that tests the degree of trust of several data sources with the same method (Moleong, 2015). This triangulation was carried out through utilization of data obtained in interview, observation and documentation. In addition, researchers also triangulated sources through: (1) comparing the results of observations, interviews and documentation between teachers, students and other parties who knew the central phenomenon.

The researcher will ask for recommendations from the research subject to direct the next informant who understands the phenomenon being studied, as Snowball sampling. Some informants who were considered to understand the central phenomenon consisted of students, teachers and several other parties in accordance with the recommendations of the previous research subjects. The data that wished to be obtained related to the implementation of project-based learning in an effort to establish entrepreneurial character in students from elementary education to secondary education at the Satya Wacana Christian Higher Education Foundation Salatiga.

\section{Data Analyses}

Researchers triangulate data using the technical triangulation from the data obtained through interview, observation and documentation techniques. In addition, the researcher also triangulated the source by comparing the results of observations, interviews and documentation between teachers, students and other parties.Data analysis used by researchers in this study is the Spradley`s domain an alysis. Some domains obtained in the field can be found, there was a semantic correlation from available data. Data Analysis Spradley (2016) was done by: a) looking for semantic relationships, b) a list of domain analysis worksheets found, c) selecting data that has similarities, d) looking for data that contain coverer and covered, e) compiling structural questions, $\mathrm{f}$ ) list the domains that have been found.

\section{FINDINGS}

Entrepreneurship learning can be given in various levels of education, starting from the basic education level to the level of secondary education in a sustainable and integrated manner. The findings in this study are entrepreneurship learning can be done with a project-based learning approach. The given project carried out in stages in learning activities in the given period of time. The results of entrepreneurship project based learning are the formation of entrepreneurial character in students. Each character at the education level had a different character achievement according to the level, difficulty and characteristics of the students.

Based on indept-interview, observation and documentation researcher determines the domain analysis obtained from the data in the field, the first domain related to project-based entrepreneurship learning from the elementary school level, junior high school to senior high school in the foundation. The pattern of semantic relations from the first domain appears in table 1 . This table describes the process of implementing entrepreneurial learning using a project-based learning approach. The second domain explains the formation of character in entrepreneurial learning. Semantic relationship patterns appear in Table 2 which illustrates the results of project learning activities that shape the character of entrepreneurship in students from elementary, middle to high school.

Based on the explanation above, the form of the first and second domain can be elaborated in the following table:

Table 1. Learning Based on Entrepreneurship Projects at Elementary, Middle School and High School

\begin{tabular}{|c|c|c|c|c|}
\hline No & Stage of & Sub Domain & Semantic & Domain \\
\hline
\end{tabular}


Rina,L., Murtini,W., \& Indriay u,M. (2018). Establishment of entrepreneurial character in the foundation based school system through project based learning. International Journal of Educational Research Review,3(4),128-140.

\begin{tabular}{|c|c|c|c|c|}
\hline & Education & & Relation & \\
\hline \multirow[t]{4}{*}{1} & Elementary & $\begin{array}{l}\text { Develop students' creativity, sensitivity, } \\
\text { independence and confidence in } \\
\text { creating based on the work process that } \\
\text { must be passed }\end{array}$ & Is part of & $\begin{array}{l}\text { Learning goal based on } \\
\text { project }\end{array}$ \\
\hline & & $\begin{array}{l}\text { Explanation of theory, project work, } \\
\text { assessment }\end{array}$ & Is stages of & $\begin{array}{l}\text { Learning process based on } \\
\text { project }\end{array}$ \\
\hline & & $\begin{array}{l}\text { Make pencil cases from used materials, } \\
\text { piggy banks from plastic bottles, } \\
\text { puppets and trash cans from used } \\
\text { cardboard, mask from Styrofoam }\end{array}$ & Is the kind of & $\begin{array}{l}\text { Project in entrepreneurship } \\
\text { learning }\end{array}$ \\
\hline & & $\begin{array}{l}\text { Limited space to save works that have } \\
\text { not yet to be completed, materials that } \\
\text { adapted to the theme given by the } \\
\text { school such as the love of the homeland. }\end{array}$ & Is the form of & $\begin{array}{l}\text { Problem in the process of } \\
\text { project based learning }\end{array}$ \\
\hline \multirow[t]{4}{*}{2} & Junior High & $\begin{array}{l}\text { Stimulating creative, innovative and } \\
\text { independent power in creating valuable } \\
\text { works to later be commercialized }\end{array}$ & Is part of & $\begin{array}{l}\text { Learning goal based on } \\
\text { project }\end{array}$ \\
\hline & & $\begin{array}{l}\text { Explanation of theories, business design, } \\
\text { surveys, presentations, project creation, } \\
\text { sales, reports }\end{array}$ & Is stages of & $\begin{array}{l}\text { Learning process based on } \\
\text { project }\end{array}$ \\
\hline & & $\begin{array}{l}\text { Making innovations from chocolate } \\
\text { materials, vases and bags from } \\
\text { newspapers, patchwork ornaments }\end{array}$ & Is the kind of & $\begin{array}{l}\text { Project in entrepreneurship } \\
\text { learning }\end{array}$ \\
\hline & & $\begin{array}{l}\text { Still lacking enthusiasm to work on } \\
\text { project tasks, collection of tasks is often } \\
\text { not timely }\end{array}$ & Is the form of & $\begin{array}{l}\text { Problem in the process of } \\
\text { project based learning }\end{array}$ \\
\hline \multirow[t]{4}{*}{3} & Senior High & $\begin{array}{l}\text { Provide real experience in } \\
\text { entrepreneurial activities in accordance } \\
\text { with the curriculum provided by the } \\
\text { government }\end{array}$ & Is part of & $\begin{array}{l}\text { Learning goal based on } \\
\text { project }\end{array}$ \\
\hline & & $\begin{array}{l}\text { Explanation of learning objectives, } \\
\text { making business plans, presenting } \\
\text { business designs, working on projects, } \\
\text { reporting }\end{array}$ & Is stages of & $\begin{array}{l}\text { Learning process based on } \\
\text { project }\end{array}$ \\
\hline & & $\begin{array}{l}\text { Handicrafts from used materials such as } \\
\text { bookshelves, decoration of cloth / batik, } \\
\text { bags, fish breeding: catfish and value of } \\
\text { and innovations of traditional regional } \\
\text { food }\end{array}$ & Is the kind of & $\begin{array}{l}\text { Project in entrepreneurship } \\
\text { learning }\end{array}$ \\
\hline & & $\begin{array}{l}\text { Facilities for storing students' work, } \\
\text { enthusiastic work assignments, less than } \\
\text { optimal care for fish breeding material }\end{array}$ & Is the form of & $\begin{array}{l}\text { Problem in the process of } \\
\text { project based learning }\end{array}$ \\
\hline
\end{tabular}

Table 2. Establishment of Entrepreneurial Characters from the Project-Based Learning Process at Elementary, Middle and High Schools in the Foundation

\begin{tabular}{|c|c|c|c|}
\hline $\begin{array}{l}\text { Stages of } \\
\text { Education }\end{array}$ & Sub Domain & $\begin{array}{c}\text { Semantic } \\
\text { Relation }\end{array}$ & Domain \\
\hline \multirow[t]{4}{*}{ Elementary } & Self-sufficient & Is the kind of & $\begin{array}{l}\text { Entrepreneurial character that is formed } \\
\text { from within students }\end{array}$ \\
\hline & Creative & & \\
\hline & Honest & & \\
\hline & Discipline & & \\
\hline \multirow[t]{3}{*}{ Junior High } & Self-sufficient & Is the kind of & $\begin{array}{l}\text { Entrepreneurial character that is formed } \\
\text { from within students }\end{array}$ \\
\hline & Creative & & \\
\hline & Responsibility & & \\
\hline
\end{tabular}




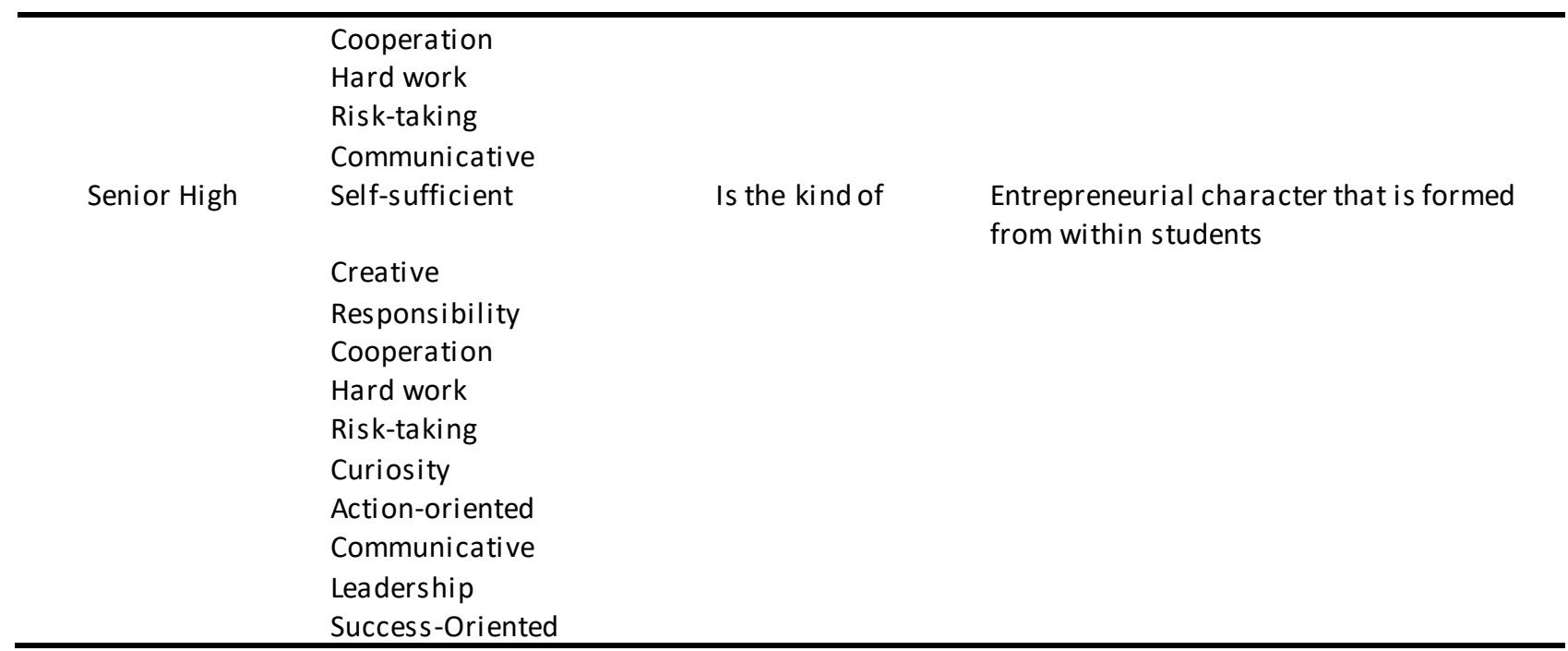

Based on the semantic relationship pattern formed in Table 1 and Table 2, researcher can analyze the work pattern of domain analysis shown in Figure 1. The work pattern contains the formation of entrepreneurial character in the foundation school system through project-based learning in relation to entrepreneurship. The character formation was obtained starting from the basic education level to the secondary education level in the Satya Wacana Christian Higher Education Foundation Salatiga, Indonesia:

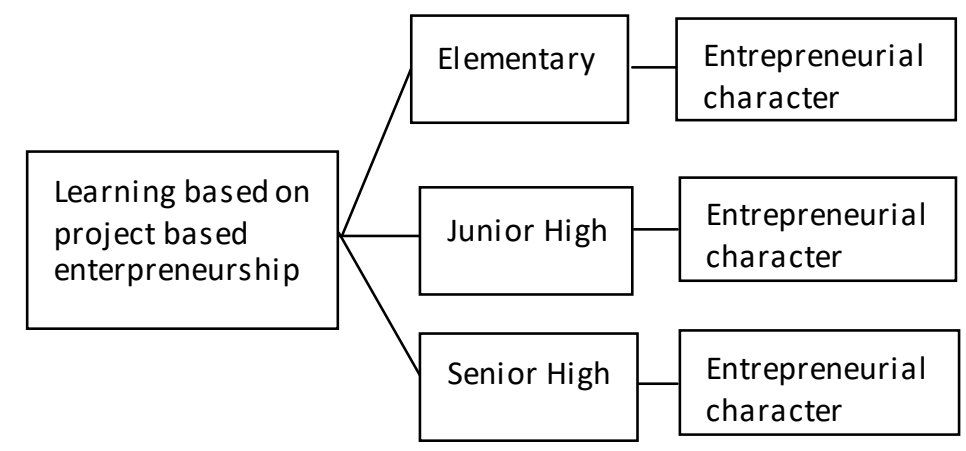

Figure 1. work pattern of domain analysis

Based on the data in Figure 1, the project-based learning process related to entrepreneurship at the elementary, junior high and high school levels was given at the Satya Wacana Christian Higher Education Foundation Salatiga, Indonesia. The process of project-based learning activities will be explained at each level starting from elementary, junior high to high school.

\section{Project Based Learning in Establishing Entrepreneurial Character in Elementary Schools}

Based on data collected through interviews, observation and documentation of informants who understood the central phenomenon of project learning in the subject of the workshops in elementary schools, the purpose of holding project based learning can be found. The project given by the teacher to the students Skills and Crafts subjects was to make products from used materials that can be changed in shape and value into a craft. According to the Skills and Crafts subject teachers the project learning objectives in Elementary School were to develop the character of students when creating work based on existing work processes: "The bottom line is the Skills and Crafts instilled sensitivity about independence, self-confidence $s$ and prioritizes the process" (S-GA. 2).

Observation results indicated that the project-based learning process is carried out in the Skills and Crafts subjects by providing assignments for making works in accordance with the classroom learning objectives. Learning process that required students to be more creative and innovative in creating certain products will stimulate them to find new things. This is also supported by research by Christina, Purwoko 
and Kusumowidagdo (2015); Robles and Rodriguez (2015) active learning fosters student activity so as to improve their competence and performance. This must be inculcated in students since childhood, in various entrepreneurial education programs at all levels of education also through lifelong learning (Bikse, Riemere \& Rivza, 2014). In fact, in accor dance with the statement of the Ministry of National Education (2010) that the goals of primary and secondary education in entrepreneurship learning in addition to having a personality who has a character, also has values in entrepreneurship according to their respective levels of education.

Skills and Crafts Learning in Elementary Schools oriented tow ards making craft projects with learning outcomes adapted to the character themes provided by the school. The project is by creating works by the students themselves. According to the teacher: "So the main thing is the process, the teacher only gives the basic material, for example, making the material from used materials, making pencils ... children develop their own shapes, colors, but I taught the principle first"(S-GA.2). The material to be delivered was in accordance with the learning objectives of each class. Based on the observation process, researchers also found students' efforts in making craftworks made pencils from old newspapers, rolled thin then shaped according to what students wanted. After making the work is done in three to four meetings the teacher assessed the results of their project.

\section{Project Based Learning in Establishing Entrepreneurial Character in Junior High}

The next school level is at the Satya Wacana Christian Middle School Salatiga, Indonesia. Based on interviews, observations and documentation obtained from informants, it can be found the project learning process in the subjects of the craft. The purpose of project learning in relation to entrepreneurial learning was to stimulate creative, innovative and independence in creating works of value later they be commercialized. According to the subject matter teacher, EH explained: "I give as best I can by empowering children to innovate in order to have an independent attitude... there is the process of at least having the thought of creating creativity that seems unimportant so that children can think of something useful later on" (S-EH. 2).

Observations on learning workshops are also shown in each class completing a predetermined project according to the learning objectives for one semester. The making of the project in this learning was oriented tow ards the use of the environment: "an example from me, waste material can later be made int o a piece of work" (S-EH.2). Some projects that must be done such as making vases and bags from newspapers, patchwork wall hangings, cardboard trash bins and so on.

In addition, the form of project learning in junior high schools was also given to grade 9 who had made entrepreneurship product projects from chocolate. The teacher, NP explained that learning started from the design of a business venture, a shop survey to purchase chocolate ingredients, presentations on product and brand design, project creation, product sales and reporting. "Students actually do not write down material but do it, actually the child knows the first part about entrepreneurship... Apart from that product there is also packaging to marketing, the process of cooking, packaging to photos and videos as their report" (S-NP.1). Some of these processes will shape their communicative character because of product presentations that will be made by coordinating and discussing with their groups.

\section{Project Based Learning in Estabilishing Entrepreneurial Character in Senior High}

The next school level is at Satya Wacana Christian High School Salatiga, Indonesia. The purpose of the project-based learning process is to provide a real experience of entrepreneurial activities in accordance with the high school curriculum: "... students make a written plan first like a proposal before our proposal gives the basis for the PKU subject matter, the material basis ..." (S-DJT .1). Besides that the next project is creating: "... the order is planning, making and then packing. Packaging is part of marketing, then there is sales..."(S-NK.1). In addition, other projects were fish farming such as catfish, tilapia or traditional food processing innovations. Students will also provide project-related report through documentation such as photos and videos. 
Thus the stages in project learning in or the Craft and Entrepreneurship lessons at Satya Wacana Christian High School consisted of an explanation of learning objectives, making a business plan, presenting business plans, working on projects, reporting. Some of these stages provided opportunities for students to discuss in groups in determining their creativity, solving group problems, developing leadership and communication skill to present their business plans in front of the class. The stages that students must go through provided them opportunity to orient themselves towards the process starting from planning, implementing and evaluating learning. Students were always encouraged to be involved in every stage of learning given by the teacher so that the entrepreneurial character can grow and be imbued in their lives.

Learning process carried out at the high school level, learning process starteded from a business plan. Business plans related to thinking about risk, curiosity and self-confidence. In addition, business plan activities will stimulated students' creative attitudes when presenting their plans in class (Barba-Sanchez and Atienza-Sahuquillob, 2018). Thus the communicative character will also be formed from this activity. Work on the project will put pressure on students to be able to w ork on projects responsibly by working together and working hard on a predetermined team. In this event, students will learn to organize, and to manage leadership activities. Initiative in dealing with the problems faced gave an orientation to the action to immediately resolve the problem..

Thus the activities that refer to the project will shape the character of entrepreneurship and the development of entrepreneurial skills as a provision for students that will be needed in the current era (Din, Anuar and Usman, 2016; Daniel, Costa, Pita and Costa, 2017). The quality required from the students, in relation to the understanding of entrepreneurship is important to be applied and given to students through projects. The teacher will only act as a companion and facilitator to students and they will work more actively in a form of student centered learning. Learning in the project can provide a lot of student experience and skills to be creative in creating products or works that can be used in developing students' entrepreneurial character.

The Ministry of National Education, Development Agency and Curriculum Center (2010) described some entrepreneurial characters that are instilled in various levels of basic education to secondary education: 1) independent, 2) creative, 3) dare to take risks, 4) action oriented, 5) leadership, 6) hard work, 7) honest, 8) discipline, 9) innovative, 10) responsibility, 11) cooperation, 12) tenacity, 13) commitment, 14) realistic, 15) curiosity, 16) communicative, and 17) strong motivation for success. Through activities in entrepreneurship education, several characters would hopefully be instilled; this could become references in further implementation, especially in intracuricular activities (Gutiérrez and Baquero, 2017). Based on the results of the study, there were only a few characters that can be formed in each level. But in the implementation the formation of the characters has not been done optimally. This However can be formed in accordance with the conditions, characteristics of students and several other factors.

The estabilishment of entrepreneurial character occurred in the process of project-based learning activities. Activities consisting of product or business design, business design presentations, project implementation activities and report of the results of project activities were stages that can be found in this study. Therefore, it is important for teachers to pay attention to learning activities based on the project in shaping entrepreneurial character in students. As explained in the previous chapter, the character of entrepreneurship is needed in the era of global competition and the development of science and technology today. By having this entrepreneurial character students are stimulated to have creative and innovative personalities in creating opportunities, cooperation with other parties and w ork hard, take risks and strive to be successful in developing a quality self, considered capable of competing in the current era.

The character of entrepreneurship formed in each level of education through project-based learning in Satya Wacana Christian Elementary School includes: independent, creative, honest, and disciplined. At the Satya Wacana Christian Middle School level, Self-sufficient, creative, responsibility, cooperation, hard w ork, 
Rina,L., Murtini,W., \& Indriay u,M. (2018). Establishment of entrepreneurial character in the foundation based school system through project based learning. International Journal of Educational Research Review,3(4),128-140.

risk-taking and communicative. As for Satya Wacana Christian High School, entrepreneurial characters formed were:Self-sufficient, creative, responsibility,cooperation, hard work, risk-taking and communicative, leadership and orientation to success.

\section{RESULT, DISCUSSION, AND SUGGESTIONS}

Based on the results of observations and interviews, the character of entrepreneurship can be formed through the implementation of entrepreneurial project-based learning. Each level has different learning outcomes that were tailored to the abilities and curriculum of the school. Welsh, Tullar and Nemati stated that formal entrepreneurship education resulted in forming students' skills, knowledge and character. Learning strategies can be prioritized to aim tow ard project-based entrepreneurship learning can shaping the entrepreneurship character (Gutiérrez and Baquero, 2017). According toFitzsimons and Turner (2013); Fernandes (2014) menyatakan bahwa project learning was identified as an effective learning in developing the skills needed by employersand prepare students in professional practice.In addition, this learning provides opportunity so that the students can be more productive, communicative and be an active participant in learning process (Riley, 2002). Robinson, Neergaard, Tanggaard, and Krueger (2016) suggested that teacher-centered entrepreneurship education must turn to be student-centered and focused on the practice of experimental lifelong learning. The teacher should focus on lifelong learning practices and provided opportunities for students to be creators in the learning process.

The results showed that in the implementation of project-based learning in each level of education had a different way in the different stages of learning. The ability of elementary school level was different from the ability found in secondary schools, as well as in high schools in the Satya Wacana Christian Higher Education Foundation Salatiga, Indonesia. Entrepreneurship education starting from the elementary level aimed to increase creativity, help determining the risk and planning while the Middle level aimed to increase aw areness of entrepreneurs who succeed in creating and maintaining a company that started small (Gutiérrez and Baquero, 2017). The implementation of entrepreneurship education at various levels of education is an effort to integrate a curriculum that focuses on character building and some skills and entrepreneurial knowledge.

The formation of entrepreneurial characters is formed from the process of entrepreneurial project-based learning activities in each level of education.Through activities in entrepreneurship education, several characters would hopefully be instilled; this could become references in further implementation, especially in intracuricular activities (Gutiérrez and Baquero, 2017). The characters that are formed in the learning process are not only sensed by students but can also be seen in the characteristics of their prominent personality (Bikse and Riemere, 2013; Luca, Cazan and Tomulescu, 2013). The process in question is the stages in the implementation of the entrepreneurship project.It can be seen that the stages in project-based learning in primary schools had been carried out in three stages: planning and theoretical explanation, project work and assessment. This process is important for students to discover real experiences in producing projects from previously acquired theories so as to increase knowledge related to student project appearance (Fernandes, 2014; Law and Chuah, 2004). Some entrepreneurial activities are based on innovative attitudes that are creative, able to solve problems from reality, and identify a problem (BarbaSanchez and Atienza-Sahuquillob, 2018).

Based on the results of the research described in the previous chapter, there were findings such as: explanation of theories, business plans, surveys, presentations, project creation, sales, reports. Business plan is the main requirement to be taught in entrepreneurship education activities (Gutiérrez and Baquero, 2017). This is because the role of the business plan is as a center of academic activity.

Based on the project learning process assigned, students will indirectly solved problems in learning activities with their own creativity (Arcidiacono, Trewn and Bucciarelli, 2016) and brainstorming to develop innovative work so that they will have an impact in analyzing and discussion activities (Barba-Sanchez and Atienza-Sahuquillob, 2018). With student-centered learning, students will develop skills in and will be responsible and independent and dare to take risks on the project given to them (Viorica - Torri, 2015). Through some of the project opportunities, students will even work hard and work together to achieve the 
planned targets in their business design. Kadir, Salim and Kamarudin stated that students' skills during the direct experience of entrepreneurship learning formed through developing a business plan and running a small business or simulation.

Stages found at the high school level provided an overview of the methods given by the teacher to practice the craft and entrepreneurship at school. Moreover, some characters were seen. This character can be seen in project learning activities. The resulting characters have not met the standard; explanation of learning objectives, making business plans, presenting business designs, working on projects, reporting. Student efforts wereformed in their creativity in creating opportunities, business through simple analysis in the implementation of Crafts and Entrepreneurship subject. Each level of education has character achievement in accordance with the development of the current students. The process of discussion and determining the product to be produced will lead them into leadership habits. In addition they will be responsible, work together and act honestly in the reporting stages that students must provide in groups. This w as the assignment that gave students the ability to design, organize and manage finances, activities and relationships with others in establishing networks.

Based on the results and discussions that have been described, it can be concluded that entrepreneurship learning carried out based on the project can shape students' entrepreneurship characters. Some characters found were different at each level of education at the Satya Wacana Christian Higher Education Foundation Salatiga, Indonesia. The entrepreneurial character that is formed at the primary school level includes: independent creative, honest, and disciplined. At the junior high school level the characters formed include: independent, creative, responsibility, cooperation, hard work, risk-taking and communicative. While the level of high school education is formed a broader character when compared with the level of junior high school, namely: independent, creative, responsibility, cooperation, hard w ork, dare to take risks, curiosity, action oriented, communicative, leadership and success orientation. This research has theoretical and practical implications. Based on theory, research contributed to the formation of students' entrepreneurial character. Research also contributed to practices of education in the use of project based learning models. To shape the character of entrepreneurs in the entrepreneurial education process, the school foundation can determine policies in integrating entrepreneurship in learning activities.

By acknowledging that project-based learning activities can shape the character of students, the educational institutions in various levels may pay special attention to the establishments of entrepreneurial characters in students. Character formation can take the form of entrepreneurship learning using project learning. How ever, this research was a qualitative research in primary to secondary education, thus the results of the study cannot be generalized. In addition, the research was conducted only in the City of Salatiga at several levels in one school foundation excluding higher education level. Entrepreneurial characters are highly needed in the current era of economic competition; researchers suggest further research to be able to use different learning methods in shaping the characters of entrepreneurship at various levels of education. In addition, researchers also suggest further research to be able to review other aspects that entrepreneurs need to possess such as knowledge, skills and competencies at various levels of education on an ongoing basis using other research methods.

\section{REFERENCES}

Akcaalan, M. (2016). Investigation of The Relationships Between Lifelong Learning And Social Emotional Learning.International Journal of Educational Research Review, 1(1), 14-20.

Arcidiacono, G., Yang, K., Trewn, J. \& Bucciarelli, L. (2016). Application of Axiomatic Design for ProjectBased Learning Methodology. Procedia CIRP, 53, $166-172$.

Barba-Sánchez, V., \&Atienza-Sahuquillob, G. (2018). Entrepreneurial intention among engineering students: The role of entrepreneurship education. European Research on Management and Business Economics, 24 (1), 53-61.

Bell, R. (2015). Developing the next generation of entrepreneurs: Giving students the opportunity to gain experience and thrive. The International Journal of Management Education, 13, 37-47. 
Rina,L., Murtini,W., \& Indriay u,M. (2018). Establishment of entrepreneurial character in the foundation based school system through project based learning. International Journal of Educational Research Review,3(4),128-140.

Bikse, V., Riemere, I., \& Rivsa, B. (2014). The Improvement of Entrepreneurship Education Management in Latvia. Procedia - Social and Behavioral Sciences, 140,69-76.

Bindah, E. V., \& Magd, H. A. E. (2016). Teaching Entreprenenurship in Oman: Successful Approaches. Procedia-Social and Behavioral Sciences, Vol. 219 pp. $140-144$.

Christina, W., Purwoko, H., \& Kusumowidagdo, A. (2015). The Role of Entrepreneur in Residence towards the Students' Entrepreneurial Performance: A Study of Entrepreneurship Learning Process at Ciputra University, Indonesia. Procedia - Social and Behavioral Sciences, 211, $972-976$.

Ciftci, S. (2015). The Effects of Using Project-Based Learning in Social Studies Education to Students' Attitudes tow ards Social Studies Courses. Procedia - Social and Behavioral Sciences, 186, $1019-1024$.

Creswell, J. (2015). Riset Pendidikan Perencanaan, Pelaksanaan, dan Evaluasi Riset Kualitatatif \& Kuantitatif Ed. Kelima. Terj. Soetjipto, H. P. \& Soetjipto, S. M. Yogyakarta: Pustaka Belajar.

Daniel, A. D., Costa, R. A., Pita, M., \& Costa, C. (2017). Tourism Education: What about entrepreneurial skills? Journal of Hospitality and Tourism Management, 30, 65-72.

Din, B. H., Anuar, A. R., \& Usman, M. (2016). The Effectiveness of the Entrepreneurship Education Program inUpgrading Entrepreneurial Skills among Public University Students. Procedia - Social and Behavioral Sciences, 224, $117-123$.

Ergül, N. R. \& Kargın, E. K. (2014). The Effect of Project Based Learning On Students' Science Success. Procedia - Social and Behavioral Sciences, 136, 537-541.

Fernandes, S. R. G. (2014). Preparing graduates for profesional practice: finsings frm a case study of Projectbased Learning (PBL). Procedia - Social and Behavioral Sciences, 139, 219-226.

Fitzsimons, J., \&Turner, R. (2013). Integrating Project-Based Learning Into an Undergraduate Programme Using Web 2.0 and Videoconferencing. Journal of Applied Research in Higher Education, 5(1), 129-140.

Goldstein, B. L., Ick, M., Ratang, W., Hutajulu, H., \& Blesia, J. U. (2016). Using The Action Research Process To Design EntrepreneurshipEducation at Cenderawasih University. Procedia - Social and Behavioral Sciences, 228, $462-469$.

Gutierrez, J. G., \& Baquero, J. E. G. (2017). New cross-proposal entrepreneurship and innovationin educational programs in third level (tertiary). Contaduría y Administración, Vol. 62 pp. 239-261.

Ismail, V. Y., Zain, E., \& Zulihar. (2015). The Portrait of Entrepreneurial Competence on Student Entrepreneurs. Procedia - Social and Behavioral Sciences, 169, $178-188$.

Kadir, M. B. A., Salim, M., \& Kamarudin, H. (2012). The Relationship Between Educational Support And Entrepreneurial Intentions in Malaysian Higher Learning Institution. Procedia - Social and Behavioral Sciences, Vol. 69 pp. $2164-2173$.

Kementerian Pendidikan Nasional Badan Pengembangan dan Pusat Kurikulum. (2010). Bahan Pelatihan Penguatan Metodologi Pembelajaran Berdasarkan Nilai-Nilai Budaya untuk Membentuk Daya Saing dan Karakter Bangsa: Pengambangan Pendidikan Kewirausahaan. Jakarta: Kementerian Pendidikan Nasional.

Küttim, M., Kallaste, M., Venesaar, U., \&Kiis, A. (2014). Entrepreneurship education at university level and students' entrepreneurial intentions. Procedia - Social and Behavioral Sciences, 110, 658-668.

Law, K. M. Y., \& Chuah, K. B. (2004). Project-Based Action Learning as Learning Approach in Learning Organisation: the Theory and Framework. Team Performance Management: an International Journal, 10 ( 7/8), 178-186.

Luca, M. R., \& Cazan, A. M. (2011). Involvement in Entrepreneurial Training and Personality. Procedia Social and Behavioral Sciences, 30,1251-1256.

Moleong, L. J. (2015). Metodologi Penelitian Kualitatif Ed Revisi. Bandung: PT Remaja Rosdakarya.

Nasr, K. B. \& Boujelbene, Y. (2014). Assessing the impact of entrepreneurship education. Procedia - Social and Behavioral Sciences, 109,712-715. 
Rina,L., Murtini,W., \& Indriay u,M. (2018). Establishment of entrepreneurial character in the foundation based school system through project based learning. International Journal of Educational Research Review,3(4),128-140.

Ökten, P. (2016). Parental Academic Support in Education. International Journal of Educational Research Review, $1(2), 18-24$.

Presiden Republik Indonesia. (1995). Intruksi Presiden Republik Indonesia No 4 Tahun 1995 Tentang Gerakan Nasional Memasyarakatkan dan Membudayakan Kewirausahaan. Jakarta: Presiden Republik Indonesia.

President of Indonesia. (1995). Instruksi Presiden Republik Indonesia Nomor 4 Tahun 1995 Tentang Gerakan Nasional Memasyarakatkan dan Membudayakan Kewirausahaan. Jakarta: President of Indonesian.

Riley, D. (2002). Simulation Modelling: educational development roles for leraning technologists. ALTJ,10(3), 54-69.

Robinson, S., Neergaard, H., Tanggaard, L., \& Krueger, N. F. (2016). New Horizons In Entrepreneurship Education: From Teacher-Led To Student-Centered Learning. Education + Training, 58(7/8), 661-683.

Robles, L. \& Rodriguez, M. Z. (2015). Key Competencies for Entrepreneurship. Procedia Economics and Finance, 23, 828-832.

Rohmawati, A. (2018). Children's Social Skills Stimulation Viewed From Early Childhood Education Unit in Indonesia. International Journal of Educational Research Review, 3 (3), 69-73.

Rokhman, F., Syaifudin, A., \& Yuliati. Character Education For Golden Generation 2045 (National Character Building for Indonesian Golden Years). Procedia - Social and Behavioral Sciences, 141, 1161-1165.

Spradley, J. P. (2016). The Ethnographic Interview. United Stated: Waveland Press, Inc.

Statistic Center of Salatiga City. (2018). Kota Salatiga Dalam Angka 2018 (Salatiga Municipaly in Figures 2018). Salatiga: Statistic Center of Salatiga City.

Viorica - Torii, C. (2015). Reflections on the Development of Responsible Learning byCapitalizing StudentCentered Educational Strategies. Procedia - Social and Behavioral Sciences, 191, 1947 - 1951.

Welsh, D. H. B., Tullar, W. L., \& Nemati, H. (2016). Entrepreneurship education: Process, method, or both?Journal of Innovation \& Knowledge, 1, 125-132. 